\title{
Retrospective Comparative Study of the Incidence of Hypocalcaemia in Total Thyroidectomy between Ain-Shams University as a Referral Center and Damanhour Medical National Institute
}

\author{
HASSAN S. TANTAWY, M.D.*; AHMED Y. EL RIFAI, M.D.* and MOHAMED A. ELSHAMY, M.Sc.** \\ The Department of General Surgery, Faculty of Medicine, Ain Shams University* and Damanhour Medical National Institute, \\ Damanhour, El Beheira**, Egypt
}

\begin{abstract}
Background: Post-operative hypocalcaemia is one of the most serious complications of total thyroidectomy with variable degrees of morbidity.

Aim of Study: The aim of this study was to to compare the incidenceandto examine several preoperative and immediate post-operative factorsfor development of hypocalcaemia after total thyroidectomy in patients who underwent total thyroidectomy in Ain-Shams University and Damanhour Medical National Institute.
\end{abstract}

Patients and Methods: This retrospective study was conducted in Ain-Shams University Hospital and Damanhour Medical National Institute in the period between December 2015 and December 2019. It included 62 patients who underwent total thyroidectomy. The data was collected from patients' files in the Record Department.

Results: There were 52 female and 10 male patients. The mean age was 38 years. Multi-nodular goiter was the most common indication of total thyroidectomy. The mean preoperative serum Ca was $8.1 \mathrm{mg} / \mathrm{dl}$ in group A and $8.3 \mathrm{mg} / \mathrm{dl}$ in group B. $3(9.7 \%)$ patients in group A and $7(22.5 \%)$ in group B developed post-operative hypocalcemia The highest frequency of transient hypocalcaemia was on ${ }^{2 n d}$ post-operative day in group A and on 0 day in group B. There was only one patient $3.2 \%$ who required calcium and vitamin D supplement for more than six months.

Conclusion: Hypocalcaemia is one of the major concerns following total thyroidectomy that can be prevented by meticulous surgical technique, identification and preservation of parathyroid glands and its vascularity. Post-operative monitoring of serum calcium \& early treatment can prevent significant morbidity.

Key Words: Hypocalcaemia - Parathyroid glands - Total thyroidectomy.

Correspondence to: Dr. Mohamed A. Elshamy, E-Mail: dr.raufelshamy@gmail.com

\section{Introduction}

TOTAL thyroidectomy is one of the most common modalities of treatment of thyroid disorders. One of the most common complications of thyroid surgery is post-operative hypocalcaemia which is defined as a serum calcium level below $8.5 \mathrm{mg} / \mathrm{dl}$ (2.1 to $2.6 \mathrm{mmol} / \mathrm{L})$ [1]

Thyroid cancer, previous thyroid surgery, huge goitre, retrosternal extension and damage or inadvertent removal of the parathyroid glands with the thyroid specimen are important risk factors of this complication. Lateral ligation of inferior thyroid artery devascularizes the parathyroid gland is a strong determinant of hypocalcaemia [2] .

Post-operative hypocalcaemia usually manifests itself in the first 24 hours post-operatively or within the 2-3 days after operation. Post-operative hypocalcaemia may be transient, resolving within a few months, or permanent, requiring lifelong oral calcium and vitamin D supplementation. In most patients it is transient and resolve spontaneously [3].

Patients can complain symptoms varying from perioral tingling and numbness to carpopedal spasms and tetany (symptomatic hypocalcaemia) or they can be asymptomatic (when only low calcium serum levels are found, defined as laboratory hypocalcaemia). Even if hypocalcaemia usually recovers in most patients within few months (transient hypoparathyroidism) [1].

Asymptomatic hypocalcaemia does not require calcium supplementation, while in patient with 
severe disturbances or symptoms of hypocalcaemia, intravenous supplementation should be implemented and patients should be released with oral calcium and vitamin D regimen until the hypoparathyroidism resolves. Intravenous calcium gluconate can be given $10-20 \mathrm{ml}$ of $10 \%$ solution slowly until the symptoms disappear, then $50 \mathrm{ml}$ of $10 \%$ calcium gluconate can be added to $500 \mathrm{ml}$ of $5 \%$ dextrose solution and administered by intravenous drip at a rate of $1 \mathrm{ml} / \mathrm{kg} / \mathrm{h} \mathrm{[4]}$.

Routine oral calcium and vitamin D supplements have been proposed to prevent the development of symptomatic hypocalcaemia and to increase the likelihood of early hospital discharge after total thyroidectomy [5].

The aim of this study was to compare the incidence of development of hypocalcaemia after total thyroidectomy in patients who underwent total thyroidectomy in Ain-Shams University and Damanhour Medical National Institute.

\section{Patients and Methods}

This retrospective study was done in Ain-Shams University Hospital and Damanhour Medical National Institute on a sample of 62 patients who underwent total thyroidectomy and satisfied the inclusion and exclusion criteria to be enrolled in the study during the period December 2015 and December 2019. The data was collected from patients' files in the Record Department under supervision of thesis supervisors. Approval was obtained from the Ethical Committee of the Department of General Surgery, Faculty of Medicine, Ain Shams University. In addition, the medical directors' offices of the hospital granted permission to use the patients' data for this study. All data had no personal identifiers and were kept confidential and therefore did not require informed consent.

\section{Enrollment of patients:}

A total number of 62 patients were finally enrolled with criteria as follows: Patients underwenttotal thyroidectomy without central neck dissection regardless of the thyroid disorder.

Patients were enrolled with exclusion criteria as follows:

1- Patients had hypocalcemia, abnormal parathyroid function or renal functionbefore the surgery.

2- Patients had a history of thyroid orother neck surgery.
3- Patients undergoing thyroid resection other than total thyroidectomy as subtotal thyroidectomy or nodal dissection.

4- Patients younger than 15 years old and older than 65 years old.

\section{Patients will be divided into two equal groups $(A \& B)$ :}

- Group (A): 31 patients underwent total thyroidectomy in Ain-Shams University Hospital.

- Group (B): 31 patients underwent total thyroidectomy in Damanhour Medical National Institute.

During surgery, all thyroid tissue was removed, including the posterior capsule and pyramidal lobe, varying upon patient condition. Total thyroidectomy was performed according to the in house standards with conventional knot tying technique. Visual monitoring of the recurrent laryngeal nerve was routinely applied. All parathyroid glands were identified. The viable parathyroids were identified and if possible preserved on an intact vascular pedicle, and those that appeared nonviable or could not be preserved were removed, autotransplanted to a muscle bed in the sternocleidomastoid.

\section{Collection of clinicopathologicalparameters} and study protocol:

Demographic, pathologic, and laboratory data of all enrolled patients were collected from electronic medical records. Clinicopathological data collected encompassed age, gender, and preoperative and post-operative serum calcium and Thyroid profile. In addition, information on the type of operation, operative time, and intraoperative management of the parathyroid gland was obtained from the surgical records.

\section{Post-operative assessment:}

- The serum calcium was tested on $1{ }^{\text {st }}$ and 2 nd post-operative day to predict post thyroidectomy hypocalcaemia, respectively.

- The duration of surgery estimated in minutes from skin incision to skin closure.

- Size of the specimen: Assessment of dimensions by centimetre of the specimen.

- Result ofhistopathological examination of specimen.

- The presence of parathyroid glands at histological specimen.

All patients were routinely supplemented with oral calcium, and dose adjustment of calcium and appropriate amounts of vitamin D was managed based on clinical symptoms. 


\section{Results}

There were statistically insignificant differences between both groups regarding age, sex as $p$-value $>0.05$. There were 52 female and 10 male patients. The mean age was (38.26 \pm 11.7 years) in group $\mathrm{A}$ and (38.23 \pm 12.5 years) in group B (Table 1$)$.

There were statistically insignificant differences between both groups regarding the cause of thyroidectomy as $p$-value $=0.251$. Multi-nodular goiter was the most common cause in both groups followed by solitary thyroid nodule (Table 2).

Table (1): Patients' demographic data.

\begin{tabular}{lccc}
\hline & $\begin{array}{c}\text { Group A } \\
\mathrm{N}=31\end{array}$ & $\begin{array}{c}\text { Group B } \\
\mathrm{N}=31\end{array}$ & $p$-value \\
\hline $\begin{array}{l}\text { Age (years): } \\
\text { Mean } \pm \text { SD }\end{array}$ & $38.26 \pm 11.7$ & $38.23 \pm 12.5$ & $0.992^{1}$ \\
$\begin{array}{l}\text { Sex }(n, \%): \\
\quad \text { Male }\end{array}$ & $2(6.5 \%)$ & $8(25.8 \%)$ & $0.081^{2}$ \\
$\quad$ Female & $29(93.5 \%)$ & $23(74.2 \%)$ & \\
Working status $(n, \%):$ & & & \\
$\quad$ Working & $29(93.5 \%)$ & $25(80.6 \%)$ & $0.143^{2}$ \\
$\quad$ Not working & $2(6.5 \%)$ & $6(19.4 \%)$ & \\
\hline 1: Independent $t$-test used. & & & \\
2: Fisher exact test used. & & & \\
*: Statistically significant as $p<0.05$. & &
\end{tabular}

Table (2): Causes of thyroidectomy among both groups.

\begin{tabular}{llll}
\hline Causes & $\begin{array}{c}\text { Group A } \\
\mathrm{N}=31\end{array}$ & $\begin{array}{c}\text { Group B } \\
\mathrm{N}=31\end{array}$ & $p$-value \\
\hline Multi-nodular goiter & $23(74.1 \%)$ & $20(64.5 \%)$ & $0.251^{1}$ \\
Solitary thyroid nodule & $2(6.5 \%)$ & $7(22.6 \%)$ & \\
Cancer thyroid & $2(6.5 \%)$ & $3(9.7 \%)$ & \\
Histopathological surprise & $1(3.2 \%)$ & $1(3.2 \%)$ & \\
Hemi thyroidectomy & $3(9.7 \%)$ & $0(0 \%)$ & \\
\hline
\end{tabular}

1: Fisher exact test used.

*: Statistically significant as $p<0.05$.

Some pre-operative data about serum Ca was recorded. There was statistically insignificant differences between both groups regarding the preoperative serum $\mathrm{Ca}$ as $p$-value $=0.928$ (Table 3 ).

Table (3): Pre-operative data among both groups.

\begin{tabular}{lccc}
\hline $\begin{array}{l}\text { Serum Ca } \\
(\mathrm{mg} / \mathrm{dl})\end{array}$ & $\begin{array}{c}\text { Group A } \\
\mathrm{N}=31\end{array}$ & $\begin{array}{c}\text { Group B } \\
\mathrm{N}=31\end{array}$ & $p$-value \\
\hline Mean $\pm \mathrm{SD}$ & $8.1 \pm 0.2$ & $8.3 \pm 1.2$ & $0.928^{1}$ \\
\hline 1: Independent $t$-test used. & & \\
*: Statistically significant as $p<0.05$. & &
\end{tabular}

This was no data about intraoperative PTH assay in both groups. The duration of surgery showed insignificant differences between both groups. Only one case in group B had intraoperative bleeding (Table 4).
Table (4): Intra-operative data among both groups.

\begin{tabular}{llll}
\hline & $\begin{array}{c}\text { Group A } \\
\mathrm{N}=31\end{array}$ & $\begin{array}{c}\text { Group B } \\
\mathrm{N}=31\end{array}$ & $p$-value \\
\hline Intraoperative PTH assay & $0(0 \%)$ & $0(0 \%)$ & \\
Duration of surgery (hrs) & $2.4 \pm 0.5$ & $2.6 \pm 0.4$ & $0.143^{1}$ \\
Bleeding & $0(0 \%)$ & $1(3.2 \%)$ & $0.524^{2}$ \\
\hline
\end{tabular}

1: Independent $t$-test used

2: Fisher exact test used.

*: Statistically significant as $p<0.05$.

Out of 62 patients $3(9.7 \%)$ patients in group A and $7(22.5 \%)$ in group B developed hypocalcemia with insignificant difference $(p=0.172)$ Fig. (1).

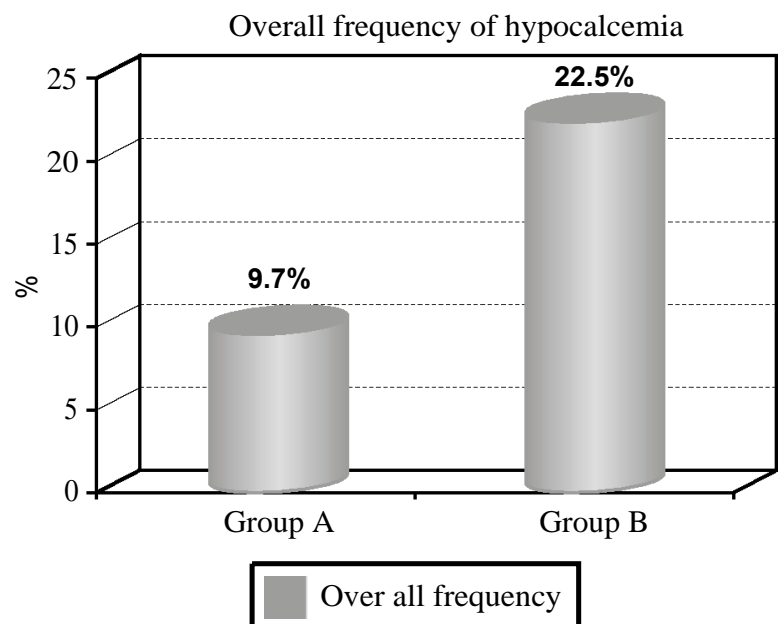

Fig. (1): Overall frequency of hypocalcaemia in both groups.

The highest frequency of transient hypocalcaemia was on 2 nd post-operative day in group $A$ and on 0 day in group B. There was only one patient $3.2 \%$ who required calcium and vitamin D supplement for more than six months post-operatively in both groups Fig. (2).

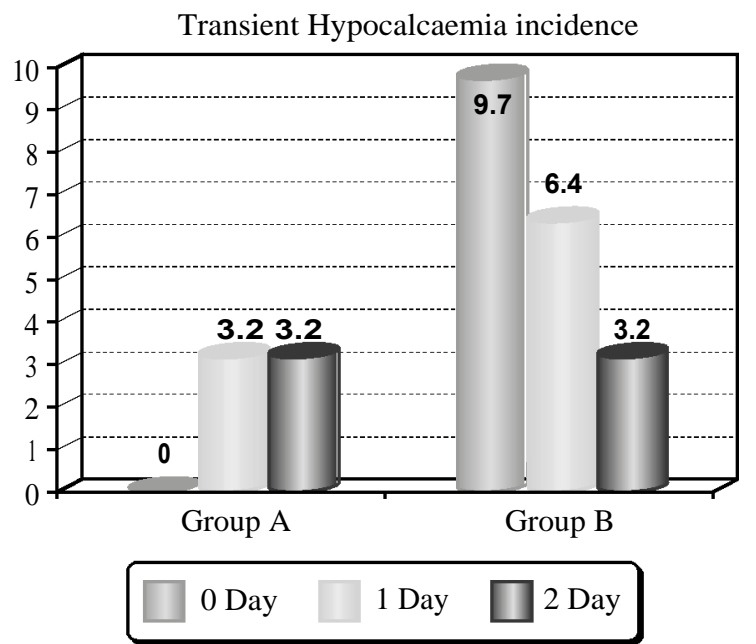

Fig. (2): Transient hypocalcaemia in both groups. 


\section{Discussion}

Hypocalcaemia is one of the most common complications following total thyroidectomy. It can be either transient or permanent [6] .

Symptomatic hypocalcamia is an extremely unpleasant sequel, it prolongs hospital stay. The symptoms include cramps, tingling sensation, paraesthesia, tetanic contractions, seizures, muscle spasms, and prolong QT interval prolongation on electrocardiogram [7]

The most common cause of post-thyroidectomy hypocalcaemia is injury to parathyroid gland. This may be due to injury, inadvertent removal, or devascularization of the parathyroid glands. Other mechanisms suggested for post-thyroidectomy hypocalcaemia comprises hungry bone syndrome in which there is rapid transfer of calcium into bones following surgical treatment of patients with pre-operative thyrotoxicosis and intraoperative haemodilution [8].

Our objective was to determine the frequency of post-operative hypocalcaemia in patients undergoing total thyroidectomy. This retrospective studyincluded a total 62 patients underwent total thyroidectomy. Patients were divided into two equal groups (A \& B): Group (A) included 31 patients underwent total thyroidectomy in Ain-Shams University Hospital and group (B) included 31 patients underwent total thyroidectomy in Damanhour Medical National Institute.

In our study a total of 62 patients' medical records were analyzed. 52 cases were females and 10 were males. The mean age was $(38.26 \pm 11.7$ years) in group A and (38.23 \pm 12.5 years) in group B.

In Baloch et al.study (2019), a total of 854 patients' medical records were analyzed. There were 670 female $(78.45 \%)$ and $184(21.54 \%)$ male patients. The mean age was 42.1 years (range 1476 years). Among the patients included, $47.3 \%$ $(\mathrm{n}=404)$ underwent total thyroidectomy and $52.69 \%$ $(\mathrm{n}=450)$ underwent completion thyroidectomy. Among these $87.58 \%(n=748)$ were malignant and $12.41 \%(\mathrm{n}=106)$ were benign [9] .

Our study found statistical insignificant differences between both groups regarding the cause of thyroidectomy. Multi-nodular goiter was the most common cause in both groups followed by solitary thyroid nodule.

Regarding pre-operative data about serum $\mathrm{Ca}$, there was statistical insignificant difference between both groups in pre-operative data about serum $\mathrm{Ca}$ ranging from 8.1 to $8.3 \mathrm{mg} / \mathrm{dl}$.

In this study the duration of surgery showed insignificant differences between both groups. Only one case had intra-operative bleeding. All patients in both groups subjected to ligation and diathermy.

Patients who have total thyroidectomy are routinely supplemented with calcium and vitamin D by many surgeons. However, this practice can reduce the number of symptomatic patients, but it can be inconvenient as treatment is expensive and poorly tolerated. It can distort the incidence rate of post-operative hypocalcaemia especially when definitions are based on serum calcium levels [10]

The ideal way is to predict which patient will develop hypocalcaemia. By this approach we can only treat patients who truly need replacement therapy. The intraoperative Parathyroid Hormone $(\mathrm{PTH})$ assay (quick PTH) has been used as a reliable and rapid method to detect hypoparathyroidisim. However, its high cost has often limited its applicability [11]

In our study, we evaluated the serum calcium on 1 st and 2 nd post-operative day to predict post thyroidectomy hypocalcaemia. Out of 62 patients $3(9.7 \%)$ patients in Ain-Shams University and 7 (22.5\%) in Damanhour Medical National Institute developed hypocalcemia with insignificant difference $(p=0.172)$. The highest frequency of transienthypocalcaemia was on 2 nd post-operative day in Ain-Shams University and on 0 day in Damanhour Medical National Institute. There was only one patient $3.2 \%$ who required calcium and Vitamin D supplement for more than six months postoperatively in both groups.

In Baloch et al., (2019) study, post-operative hypocalcaemia was observed in $7 \%$ of 854 patients undergoing total and completion thyroidectomy [9].

Esimontas et al., (2018) reported the highest incidence of transient hypocalcaemia (64.2\%) in 257 patients [12]. In previous local study transient hypocalcaemia was $21.62 \%$ in 74 patients which is higher than our results. However, different studies used different definitions and are not comparable [13].

Edafe et al., (2017) reported 5.5\% rate of permanent hypocalcaemia in 220 patients [8]. Mehanna et al., (2010) reported hypocalcemia after total 
thyroidectomy to occur in 0.33 to $65 \%$ of cases [14]. Asari et al., (2008) reported an incidence of $1.6 \%$ to $50 \%$ [15].

Following thyroid surgery the range of postoperative hypocalcaemia reported in literature varies widely. There are various factors which accounts for these differences in literature such as definition of hypocalcaemia, type of thyroid disease, and surgical technique for thyroidectomy. Patient who had total thyroidectomy with central lymph node dissection had an increased risk of temporary hypocalcaemia [8].

Asari et al., (2008) found that total serum calcium levels alone; measured during the first 2 postoperative days, cannot predict transient hypoparathyroidism correctly. They agreed that day one post-operative PTH measurements may be considered as the most reliable predictor for determining transient or permanent hypoparathyroidism [15].

Asari et al., (2008) commented on intraoperative monitoring of PTH levels recommending that levels that were less below the normal range at the end of or immediately after the operation were highly correlative with post-operative hypoparathyroidism and seemed to allow for early prediction, with a sensitivity and specificity ranging from $71 \%$ to $100 \%$ [15]

Falch et al., (2018) founded that patients with a surgery time > $189 \mathrm{~min}$ had significantly more often a post-operative hypocalcemia than those with shorter surgery time $(18.3 \%$ vs. $28.3 \%, p=$ $0.002)$. Patients with parathyroid gland reimplantationalso had a significant higher rate of initial post-operative biochemical hypocalcemia ( $45 \%$ vs. $21.5 \%, p=0.001)$. In a multivariate logistic regression analysis, only surgery time, a female gender and parathyroid gland reimplantation were the significant independent predictors for initial post-operative biochemical hypocalcemia [16]

\section{Conclusion:}

Hypocalcaemia is one of the major concerns following total thyroidectomy. Meticulous surgical technique, identification and preservation of parathyroid glands and its vascularity is essential in preventing post-operative hypocalcaemia following total thyroidectomy. Post-operative monitoring of serum calcium \& early treatment can prevent significant morbidity. These findings were important for guiding surgeons to prevent the occurrence of hypocalcemia and hypoparathyroidism.

\section{References}

1- DOCIMO G., RUGGIERO R., CASALINO G., DEL GENIO G., DOCIMO L. and TOLONE S.: Risk factors for post-operative hypocalcemia. Updates in Surgery, 69 (2): 255-60, 2017.

2- SALMAN W.A., AL BERMANI M.K. and ABED A.B.: The incidence and risk factors of hypocalcaemia after thyroid surgery. Journal of the Faculty of Medicine, 60 (1): 9-13, 2018.

3- BALOCH N., TAJ S., ANWER M. and NASEEM M.: Frequency of hypocalcaemia following total thyroidectomy. Pakistan Journal of Medical Sciences, 35 (1): 2625, 2019 .

4- ALGARNI M., ALZAHRANI R., DIONIGI G., HADI A.H. and ALSUBAYEA H.: Parathyroid hormone and serum calcium levels measurements as predictors of postoperative hypocalcemia in total thyroidectomy. Gland surgery, 6 (5): 428-32, 2017.

5- NAIR K. S., GAMALIAL J. and RAJESH P.S.: A prospective study to determine the role of routine prophylactic oral calcium and Vitamin D supplements in prevention of transient hypocalcaemia after total and near total thyroidectomy. International Surgery Journal, 5 (1): 2925, 2017.

6- EISMONTAS V., SLEPAVICIUS A., JANUSONIS V., ZEROMSKAS P., BEISA V., STRUPAS K. and MARTINKENAS A.: Predictors of post-operative hypocalcemia occurring after a total thyroidectomy: Results of prospective multicenter study. BMC Surg., 18 (1): 55-9, 2018.

7- GIORDANO D., VALCAVI R., THOMPSON G.B., PEDRONI C., RENNA L., GRADONI P. and BARBIERI $\mathrm{V}$.: Complications of central neck dissection in patients with papillary thyroid carcinoma: Results of a study on 1087 patients and review of the literature. Thyroid, 22 (9): 911-7, 2012.

8- EDAFE O., PRASAD P., HARRISON B.J. and BALASUBRAMANIAN S.P.: Incidence and predictors of postthyroidectomy hypocalcaemia in a tertiary endocrine surgical unit. Ann. R. Coll. Surg. Engl., 96 (3): 219-23, 2014.

9- BALOCH N., TAJ S., ANWER M. and NASEEM M. Frequency of hypocalcaemia following total thyroidectomy. Pak. J. Med. Sci., 35 (1): 262-8, 2019.

10- KUMAR S., KANDHASAMY S.C., SANGWAN A., GUNASEKARAN G., RAMASAMY R. and MEENA S.K.: Early prediction of hypocalcaemia following total thyroidectomy by serial parathyroid hormone and ionized calcium assay. Int. Surg. J., 3 (3): 1611-7, 2016.

11- CALÒ P.G., PISANO G., LOI G., MEDAS F., BARCA L., ATZENI M. and NICOLOSI A.: Intraoperative parathyroid hormone assay during focused parathyroidectomy: The importance of 20 minutes measurement. BMC Surg., 13 (1): 36-43, 2013.

12- EISMONTAS V., SLEPAVICIUS A., JANUSONIS V. ZEROMSKAS P., BEISA V., STRUPAS K. and MARTINKENAS A.: Predictors of post-operative hypocalcemia occurring after a total thyroidectomy: Results of prospective multicenter study. BMC Surg., 18 (1): 55-64, 2018. 
13- IQBAL M.A.Z.H.A.R., SUBHAN A.N.I.S., BAIG M.S and SHAH M.S.: Frequency of hypocalcaemia in total thyroidectomy. J. Surg. Pak., 15 (2): 87-91, 2010.

14-MEHANNA H.M., JAIN A., RANDEVA H., WATKINSON J. and SHAHA A.: Post-operative hypocalcemia-the difference a definition makes. Head Neck-J. Sci. Spec., 32 (3): 279-83, 2010.

15- ASARI R., PASSLER C., KACZIREK K., SCHEUBA C. and NIEDERLE B.: Hypoparathyroidism after total thyroidectomy: A prospective study. Arch. Surg., 143 (2): 132-7, 2008.

16- FALCH C., HORNIG J., SENNE M., BRAUN M., KONIGSRAINER A., KIRSCHNIAK A. and MULLER S.: Factors predicting hypocalcemia after total thyroidectomyA retrospective cohort analysis. Int. J. Surg., 55: 46-50, 2018 .

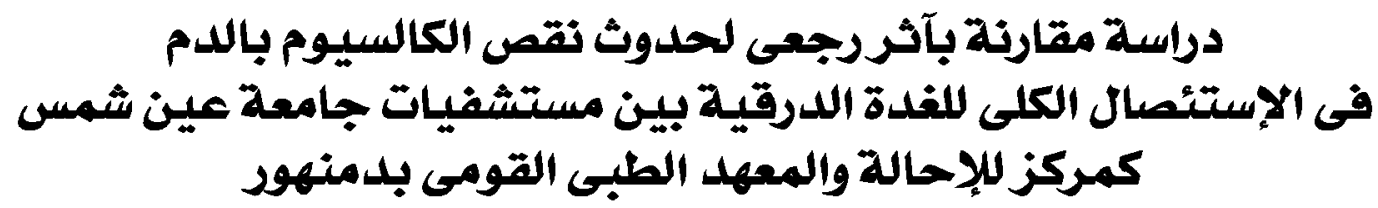

آمراض الفدة الدرقية هى آمراض شائعة مع آسباب متنوعة، إستئصال الفدة الدرقية الكلى هو آحد طرق علاج إضطرابات الفدة الدرقية.

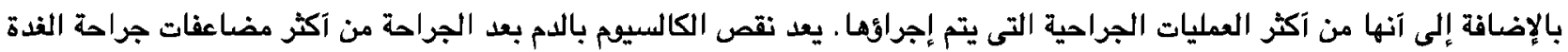
الدرقية.

الهدف من الدراسة: هو مقارنة معدلات الإصابة بنقص الكالسيوم فى الدم بعد إستئصال الفدة الدرقية الكلى فى المرضى الذين خضعوا

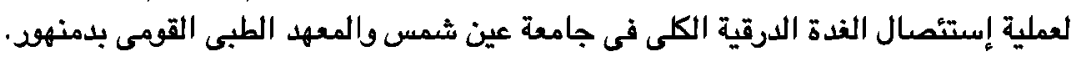

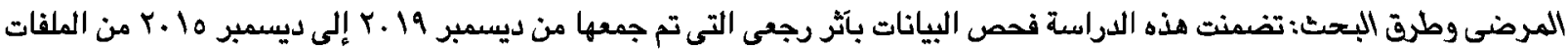

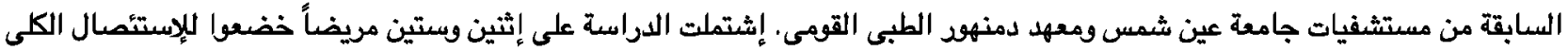

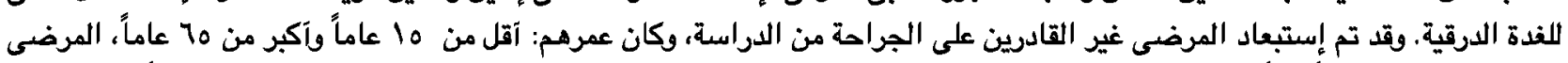

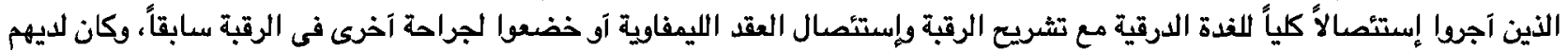

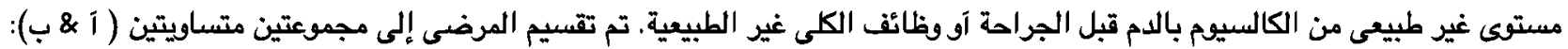

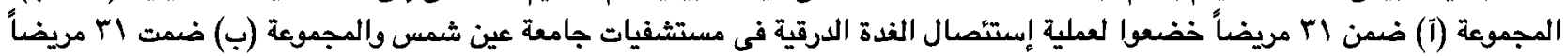

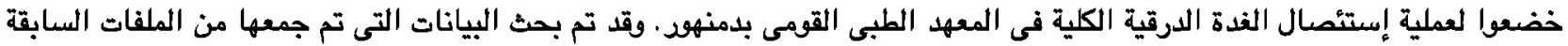

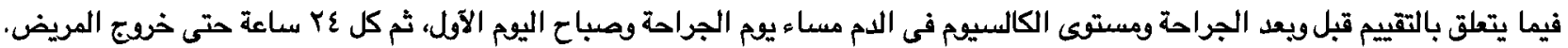
الخلاصة: يعتبر نقص الكالسيوم بالدم آحد المضاعفات الرئيسية بعد الإستئمال الكلى للغدة الدرقية. تعتبر التقنية الجراحية الدقيقة،

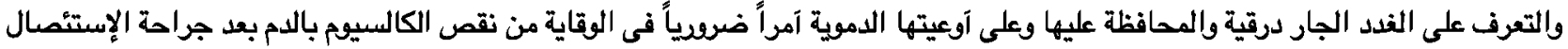

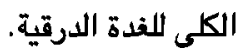

